\section{Europe underestimates cost of space programme}

\section{- ESA Paris meeting to review budget - Trading national space projects}

\section{London}

THE European Space Agency (ESA) has underestimated by more than $£ 600$ million (1,100 million European Currency Units, ECU) the amount needed annually to fund its new space programme, precipitating a major rescheduling of its proposed international research projects.

The British National Space Centre (BNSC) says the cost of the programme will be 2,800 million ECU, a third more than the previously expected cost.

The 13 nations that comprise ESA will need to curtail their space programme substantially, or demand even more money from the members. An ESA council meeting is scheduled for the end of this week in Paris, when members will be asked to declare their commitment to the space plan and to discuss a revamped programme.

ESA had agreed in Rome in 1985 to increase the European space budget by nearly 70 per cent over three years. The basic outline of the programme had also been agreed, at an estimated cost of 1,750 million ECU a year at the peak of the programme in 1990

There is likely to be considerable friction over the projects to be jettisoned to bring down the cost of the programme. France is keen to develop the Hermes spaceplane and the Ariane heavy launcher; West Germany, Italy and the United Kingdom have given support to the space station project.

BNSC still awaits a response to the 15year space plan presented to the government last summer (see Nature 324, 197. 1986). Attempts were made two weeks ago to get together all the relevant government departments to agree a space budget - expected to be about $£ 200$ million a year, with half spent within the United Kingdom - but it failed to take place. Ministerial discussions are still in progress.

\section{British Labour Party science policy}

ON Thursday 26 March 1987, Nature will be providing a forum in London at which Labour Party representatives will outline their policy on science.

As space is limited, anybody wishing to attend should telephone Neil Crombie in London on 01-836 6633, extension 2480.
The UK space programme is at present largely funded through the Departments of Trade and Industry and of the Environment and the Ministry of Defence. The BNSC plan would bring all this support under its own control, an option likely to be vigorously opposed by the relevant ministers.

The ESA meeting this week will demand not only that the members make a commitment to Europe's long-term space hopes but will also be one of many to prepare for an ESA ministerial summit scheduled for June.

ESA members have been particularly concerned about developing space for peaceful use, and are still disturbed about US intentions to devote military resources to the space station, previously considered a civil project (see Nature 325, 563; 1987).

Norway and Austria became full members of ESA this year, joining West Germany, Ireland, France, Denmark, the United Kingdom, the Netherlands, Spain, Italy, Sweden, Switzerland and Belgium. Finland has associate member status and Canada has a 'special arrangement'.

The shortfall in the ESA budget (costs at 1985 prices) could provoke serious disharmony within the group. Members are keen to pursue space technology, but each project is assessed individually; horse trading will begin this week, with each country trying to ensure its share of the research and development cake.

The ESA members are well aware of the opportunity now afforded them as a result of the mishaps experienced by the US space shuttle programme. The development of the Ariane $\mathrm{V}$ heavy launcher, in particular, could offer substantial commercial opportunities to the Europeans for launching civil communications satellites, although fierce competition is expected from Japan, China and the Soviet Union.

Europe has also been keen to promote more use of the European Communications Satellite network. Two satellites have already been launched and carry television and telecommunications signals to most parts of Western Europe.

The race within Europe to gain a foothold in direct broadcasting by satellite is now under way, with France, West Germany and the United Kingdom in the front line. Reliable launchers and space communication technology will be fundamental in ensuring the success of these programmes.
Bill Johnstone

\section{Protropin status questioned by FDA decision Washington}

A DECISION by the US Food and Drug Administration (FDA) may cause the biotechnology company Genentech to lose its position as market leader in sales of recombinant human growth hormone (rhGH). Last week, FDA granted approval to Eli Lilly \& Co. to market another version of the hormone in a move that could change the interpretation of the 1983 Orphan Drug Act.

Genentech's rhGH, tradenamed Protropin, is a 192-amino-acid protein, consisting of the 191-amino-acid hormone normally found in humans plus an extra methionine residue at the amino-terminal end, an artefact of recombinant production in Escherichia coli.

Protropin was granted approval by FDA in 1985 under the Orphan Drug Act, as a treatment for children with insufficient growth hormone. The act provides financial incentive for manufacturers to develop drugs for rare diseases, where they cannot expect to recoup development costs, let alone make a profit and entitles the manufacturer to exclusive marketing rights for seven years.

But human growth hormone sales could reach $\$ 70-80$ million in the next year, and many believe orphan drug status should not have been granted. Last year, all of Genentech's \$43.6 million product income resulted from sales of Protropin. Such success prompted three other companies, Ares-Serono, Bio-Technology General, and Eli Lilly, to apply for marketing approval of variants of $\mathrm{rhGH}$ lacking the initiation methionine.

Eli Lilly's drug, Humatrope, is also produced in $E$. coli, but does not bear the amino-terminal methionine. Eli Lilly claims its methionyl-free rhGH is less antigenic than Genentech's, and because it has a different structure, it should also be given orphan drug status. Last week the FDA concurred, and gave Humatrope marketing approval.

Genentech is contesting that approval infringes the seven-year marketing exclusivity it is entitled to for Protropin. On 6 March, Genentech filed suit against FDA in federal court in Washington, to force FDA to clarify how the act applies to genetically-engineered drugs. It also filed a preliminary injunction against Eli Lilly to prevent them from marketing Humatrope, and this hearing is scheduled for 26 March. Genentech is also seeking orphan drug approval for its own methionyl-free version of rhGH. The result of all of this could be a complete redefinition of the Orphan Drug Act. 